\title{
Union Membership and Employment Dynamics: The Role of the Union Objective Function
}

\author{
Marcus Dittrich ${ }^{1,2}$ \\ ${ }^{1}$ Faculty of Applied Economics, School of Management, Deggendorf Institute of Technology, Deggendorf, Germany \\ ${ }^{2}$ CESifo, Munich, Germany \\ Email: marcus.dittrich@th-deg.de
}

How to cite this paper: Dittrich, M. (2019) Union Membership and Employment Dynamics: The Role of the Union Objective Function. Theoretical Economics Letters, 9, 1473-1479.

https://doi.org/10.4236/tel.2019.95094

Received: May 3, 2019

Accepted: June 16, 2019

Published: June 19, 2019

Copyright (c) 2019 by author(s) and Scientific Research Publishing Inc. This work is licensed under the Creative Commons Attribution International License (CC BY 4.0).

http://creativecommons.org/licenses/by/4.0/

(c) (i) Open Access

\begin{abstract}
This paper studies the behaviour of a labour union in a model with employment and membership dynamics. It is known from the literature that the relative level of employment between intertemporal and static union models is affected by the structure of the union density function. We show that this result does not hold in general but rather that it depends on the union objective function. If the union maximises the wage bill of their members, employment in the intertemporal model will differ from employment in the static model depending on the union density function. However, if the union maximises the rent from unionisation, the intertemporal model will yield the same level of employment as the static model regardless of the union density.
\end{abstract}

\section{Keywords}

Unions, Employment Dynamics, Union Membership, Union Objective Function

\section{Introduction}

Collective bargaining and labour unions that represent the interests of different workers are important institutional factors in many labour markets. Although union membership has declined over the last several years, the proportion of workers covered by collective agreements measured in terms of the bargaining coverage is about $50 \%$ in the OECD [1]. In other words, about half of all labour contracts are affected by unions to some extent. Thus, unions still significantly influence workers' wages and employment in many countries.

The economic aspects of unions have been broadly discussed in the literature [2] [3]. Most theoretical approaches are based on static models in which unions' preferences depend on current variables. In these models, unions often maximise an objective function that depends on wages and employment. More spe- 
cifically, the two approaches most frequently used assume that the union maximises either the total wage bill of its members or the rent acquired from unionisation. In static models, the two approaches yield the same wage and employment levels. Therefore, these objective functions are often treated very similarly [3] [4] [5].

Considering the evolution of union membership over time, [6] and [7] have introduced dynamics into union models. The authors assume that unemployed workers leave the union, which may happen if the wages set by the union are too high, thus resulting in higher unemployment rates. Unions that maximise the utility of both current and future members can expand membership, and, in turn, improve their utility, through increasing employment. This situation leads to the major finding of [6] and [7] that static models overstate the labour market distortions caused by unions.

A more plausible union density function is proposed by [8]. In their model, if the union is more successful in raising workers' wages, workers will have a higher propensity to join the union. This relationship gives the union an incentive to accept fewer employees in an intertemporal framework than in a static model. A model for membership decisions based on stochastic demand and differential layoff rates for union and non-union workers is provided by [9]. In their model, union membership increases when the advantage of being a member exceeds the advantage of not being a member. [10] extends the model of [6] and [7] by the level at which wage-setting takes place. They show that static models overstate the distortions caused by unions only in the special case of firm-level wage setting; with centralised wage-setting, static models may actually lead to higher employment than dynamic models.

Examining dynamic models of union wage-setting is an important step to better understand what unions do. The studies mentioned above, however, do not focus on the role of the union objective function. Our paper aims to fill this gap. We analyse the impact of the particular forms of the objective function (wage bill maximizing or rent maximizing) on employment and membership dynamics and on the steady state results. We show that the static model and the intertemporal model yield the same level of employment when unions maximise the rent collected from unionisation. If unions maximise their members' wage bill, however, employment in the intertemporal model may differ from the static model depending on the functional form of the union density. Our results indicate that a precise definition of the empirically relevant union objective function is needed.

This paper proceeds as follows. Section 2 sets up the intertemporal labour market framework. Section 3 includes an analysis of employment and membership dynamics. The steady state results are discussed in Section 4. Finally, Section 5 offers conclusions.

\section{The Labour Market Framework}

The firm's production function is given by $f\left(n_{t}\right)$, with $f^{\prime}\left(n_{t}\right)>0$ and 
$f^{\prime \prime}\left(n_{t}\right)<0$, where $n_{t}$ denotes employment in period $t$. The firm's profit is $\Pi_{t}=p f\left(n_{t}\right)-w_{t} n_{t}$, where $p$ is the price of the output good and $w_{t}$ is the worker's nominal wage. The firm's labour demand results from the marginal productivity condition and is implicitly given by

$$
f^{\prime}\left(n_{t}\right)=\frac{w_{t}}{p} .
$$

We assume that the wage is set by a monopoly union. The union chooses the wage that maximises its objective function. Given this wage, the firm then chooses the level of employment according to its labour demand (1). The objective function of the monopoly union is given by

$$
U_{t}=n_{t}\left(w_{t}-b_{t}\right)+\rho m_{t} b_{t},
$$

where $m_{t}$ denotes the number of union members, $b_{t}$ is the unemployment benefit, and $\rho \in[0,1]$ is a measure of the weight of unemployed members. Thus, Equation (2) is a general objective function which captures the specific functional forms discussed above. When $\rho=0$, this indicates that the union maximises the difference between the wage and the unemployment benefit, i.e., the rent from unionisation. When $\rho=1$, the union maximises the total wage bill of its members.

This formulation reflects the seminal discussion of the appropriate union objective function. On the one hand, [11] and [12] argue that unions maximise the real wage surplus. On the other hand, [13] and [14] contend that unions maximise the total income of their members. An alternative interpretation of equation (2) stems from the insider-outsider theory, which defines employed workers as insiders and unemployed workers as outsiders. If $\rho=0$, the objective function could be interpreted such that the union only cares for its employed members because of, for example, high insider power. If $\rho=1$, the union cares for employed and unemployed members equally. All intermediate cases with some insider power are captured by $0<\rho<1 \quad$ [15].

Regarding the union membership dynamics, we assume that unemployed members leave the union [6] [7]. Moreover, as proposed by [8], we assume that only a portion of all employees join the union and that more workers join the union as the union sets higher wages. This formalisation of union membership dynamics is supported by empirical evidence that workers' propensity to join a union is positively related with union wages. Formulating the model in continuous time while omitting the time index (for simplicity of notation), we can express membership dynamics by

$$
\dot{m}=\sigma(w) n-m,
$$

where $\sigma(w)$, with $\sigma^{\prime}(w)>0$ and $\sigma^{\prime \prime}(w)<0$, is the proportion of employed workers who join the union.

\section{Employment and Membership Dynamics}

We now examine the dynamic aspects of employment and membership deter- 
mination. Our starting point is the intertemporal formulation provided by [6], [7], and [8], which we generalise regarding the two possible union objectives, the rent from unionisation and the wage bill. The maximization problem of the monopoly union reads as

$$
\begin{aligned}
& \max _{n} \int_{0}^{\infty}\left\{n\left(p f^{\prime}(n)-b\right)+\rho m b\right\} \mathrm{e}^{-r t} \mathrm{~d} t \\
& \text { s.t. } \quad \dot{m}=\sigma\left[p f^{\prime}(n)\right] n-m,
\end{aligned}
$$

where $r$ denotes the rate of time preference. The current-value Hamiltonian appropriate to the optimization problem (4) can be expressed by

$$
\mathcal{H}=n\left[p f^{\prime}(n)-b\right]+\rho m b+\lambda\left[\sigma\left(p f^{\prime}(n)\right) n-m\right]
$$

where $\lambda$ is the co-state variable, $m$ is the state variable, and $n$ is the control variable. The first-order conditions are

$$
\begin{gathered}
\mathcal{H}_{n}^{\prime}=\beta(n)-b+\lambda \alpha(n)=0 \\
\mathcal{H}_{m}^{\prime}=\rho b-\lambda=-\dot{\lambda}+r \lambda,
\end{gathered}
$$

with $\beta(n)=p f^{\prime}(n)+n p f^{\prime \prime}(n), \quad \beta^{\prime}(n)<0$, and

$$
\begin{gathered}
\alpha(n)=\sigma\left(p f^{\prime}(n)\right)+\sigma^{\prime}\left(p f^{\prime}(n)\right) p f^{\prime \prime}(n) n \text {. From (6) we obtain } \\
\lambda=\frac{-\beta(n)+b}{\alpha(n)} .
\end{gathered}
$$

Differentiating (8) with respect to $t$ gives

$$
\dot{\lambda}=\frac{\dot{n}\left[-\beta^{\prime}(n) \alpha(n)-(-\beta(n)+b) \alpha^{\prime}(n)\right]}{\alpha(n)^{2}} .
$$

Finally, substituting equations (8) and (9) into (7) yields the following equation, which implicitly defines the time path for employment:

$$
\frac{\dot{n}\left[-\beta^{\prime}(n) \alpha(n)-(-\beta(n)+b) \alpha^{\prime}(n)\right]}{\alpha(n)}=(1+r)[-\beta(n)+b]-\rho b \alpha(n)
$$

The employment path (10) and the evolution of union membership (3) describe the solution path for the union's intertemporal maximisation problem. In the following discussion, however, we focus only on employment and membership in the steady state, where $\dot{n}=\dot{m}=0$ hold. From (3) and (10), we derive the following steady state conditions:

$$
\begin{aligned}
& \beta\left(n^{*}\right)=b-\frac{\rho \alpha\left(n^{*}\right)}{1+r} b \\
& m^{*}=\sigma\left(p f^{\prime}\left(n^{*}\right)\right) n^{*}
\end{aligned}
$$

\section{Steady State Results}

We first compare steady state employment given by Equation (11) with the result of the static model where employment $n^{s}$ is given by 


$$
\beta\left(n^{s}\right)=b
$$

The structure of the union objective function clearly does not affect the static result. That is, Equation (13) is independent of $\rho$. Employment-and thus, the union-set wage-is the same under a wage-bill-maximising union as it is under a rent-maximising union. This result might explain why both objective functions are treated very similarly in most union models.

However, this independency result does not hold if we model union behaviour in an intertemporal framework. If the union maximises the wage bill $(\rho=1)$, the results derived for employment and membership in the steady state confirm the findings of [6] and [7]. Compared with the static equilibrium employment given by (13), in the dynamic model, the time preference rate $r$ enters the steady-state employment given by Equation (11). As the union considers that unemployed members will end their membership, the union sets a higher employment level compared to that of the static case. This result only holds because the union density in the model of [6] and [7] is fixed (i.e. $\sigma=\alpha=1$ ).

For $\rho=1$, our result is also in line with the findings of [8], who propose that $\sigma(w)>0$ in their model, resulting in $\alpha\left(n^{*}\right) \gtrless 0$. If union density is not fixed but instead depends on the wage set by the union, employment in the dynamic model is higher (lower) than in the static case if $\alpha\left(n^{*}\right)>(<) 0$. This result stems from two conflicting effects: On the one hand, higher employment increases union membership. On the other hand, a higher wage-resulting in lower employment-increases workers' propensity to join the union. Equation (11) shows that this result remains unchanged in our model if the union maximises the wage bill.

If the union maximises the rent from unionisation, however, we have $\rho=0$. In this case, the steady-state employment in Equation (11) reduces to $\beta\left(n^{*}\right)=b$, which is the same result that is derived from Equation (13) for the static model. That is, neither the time preference rate nor the union density affect employment in the steady state.

This result has some interesting implications. If the union's objective is characterised by maximizing the rent from unionisation, then membership dynamics do not affect optimal employment. Unlike in static models, the two objective functions should not be treated similarly because they lead to different results.

For cases where $0<\rho<1$, Equation (11) indicates that the comparison between static and dynamic employment is driven by three effects. Two of these are conflicting effects that are discussed above and which stem from $\alpha\left(n^{*}\right) \gtrless 0$. The third effect that determines whether employment in the dynamic model is greater than in the static model pertains to the weighting factor $0<\rho<1$.

\section{Conclusions}

We studied the behaviour of a labour union in a model with employment and membership dynamics. Our results suggest that the structure of the union objective function plays a decisive role in an intertemporal union model. Contrary to 
a static model, in which maximising the wage bill leads to the same level of employment as maximising the wage surplus, the union objective function affects the level of employment in an intertemporal framework with membership dynamics. If the union maximises the wage surplus, the intertemporal model yields the same result as the static model. If the union maximises the wage bill, however, employment in the intertemporal model differs from that of the static model. In this case, the question whether the intertemporal model overstates or understates the distortions caused by unions depends on the form of the union density function.

The primary conclusion of this research is that the form of the union objective function plays a more important role than that implied by conventional static models. This result may be important in gaining a better understanding of the behaviour of labour unions. Future research could focus on empirically testing the union objective function and the determinants of membership dynamics.

\section{Conflicts of Interest}

The author declares no conflicts of interest regarding the publication of this paper.

\section{References}

[1] OECD (2018) Employment Outlook. OECD, Paris. https://doi.org/10.1787/empl_outlook-2018-en

[2] Oswald, A.J. (1985) The Economic Theory of Trade Unions: An Introductory Survey. Scandinavian Journal of Economics, 87, 160-193. https://doi.org/10.2307/3439820

[3] Kaufman, B.E. (2002) Models of Union Wage Determination: What Have We Learned Since Dunlop and Ross? Industrial Relations. A Journal of Economy and Society, 41, 110-158. https://doi.org/10.1111/1468-232X.00238

[4] Pencavel, J. (1991) Labor Markets under Trade Unionism: Employment, Wages, and Hours. Basil Blackwell, Oxford.

[5] Booth, A.L. (1995) The Economics of the Trade Union. Cambridge University Press, Cambridge.

[6] Jones, S.R.G. (1987) Union Membership and Employment Dynamics. Economics Letters, 25, 197-200. https://doi.org/10.1016/0165-1765(87)90060-7

[7] Kidd, D.P. and Oswald, A.J. (1987) A Dynamic Model of Trade Union Behaviour. Economica, 54, 355-365. https://doi.org/10.2307/2554449

[8] Chang, J.-J. and Lai, C.-C. (1997) Union Membership and Employment Dynamics with Endogenous Union Density. Economics Letters, 57, 119-125. https://doi.org/10.1016/S0165-1765(97)81888-5

[9] Jones, S.R.G. and McKenna, C.J. (1994) A Dynamic Model of Union Membership and Employment. Economica, 61, 179-189. https://doi.org/10.2307/2554956

[10] Dittrich, M. and Schirwitz, B. (2011) Union Membership and Employment Dynamics: A Note. Economics Letters, 110, 38-40.

https://doi.org/10.1016/j.econlet.2010.09.012

[11] Rosen, S. (1970) Unionism and the Occupational Wage Structure in the United 
States. International Economic Review, 11, 269-286.

https://doi.org/10.2307/2525669

[12] de Menil, G. (1971) Bargaining: Monopoly Power versus Union Power. MIT Press, Cambridge, MA.

[13] Hieser, R.O. (1970) Wage Determination with Bilateral Monopoly in the Labour Market: A Theoretical Treatment. Economic Record, 46, 55-72. https://doi.org/10.1111/j.1475-4932.1970.tb02464.x

[14] Johnston, J. (1972) A Model of Wage Determination under Bilateral Monopoly. The Economic Journal, 82, 837-852. https://doi.org/10.2307/2230254

[15] Dittrich, M. (2010) Welfare Effects of Local versus Central Wage Bargaining. LABOUR: Review of Labour Economics and Industrial Relations, 24, 26-34. https://doi.org/10.1111/j.1467-9914.2010.00469.x 